\title{
Investigation of the Scope of Intellectual Services in the Aspect of Virtualization and Information Economy of Modern Russia
}

\author{
Dmitry Shkurkin ${ }^{1}$ \\ Vladimir Novikov² \\ Iskandar Kobersy ${ }^{3}$ \\ Issa Kobersy ${ }^{4}$ \\ Anna Borisova ${ }^{3}$ \\ ${ }^{1}$ Limited Liability Company «ELDirect» \\ ${ }^{2}$ Russia Southern Institute of Management, Russia \\ ${ }^{3}$ Don State Technical University, Russia \\ ${ }^{4}$ Sakr Power Group, Lebanon
}

Doi:10.5901/mjss.2015.v6n5s3p217

\section{Abstract}

The article deals with the scope of intellectual services, analyzes the factors and aspects of the scope of intellectual services. In the XXI century. Came the realization that the information economy, along with virtual economies are in a bundle, the article defines the place of the basic constructs such as «knowledge», «information», human capital». The article discusses the determinants of the functioning of the virtual economy, the national innovation system, analyzes the role and principles of operation of virtual enterprises, the authors attempt a graphic description of the transition economies in virtual reality, are considered agents of the virtual economy.

Keywords: services, intelligence services, virtual economy, information economy, knowledge.

\section{Introduction}

The global competition in "economy of knowledge" transforms not only the structural, but also functional contours of world economic economy which are shown in its such major characteristics as domination of the service industry, growth of knowledge intensity, an information, integration of production, forming of socially oriented type of economy, and also review of scientific and educational concepts of development of a human capital.

Let's note that the sphere of intellectual services (in research we define intellectual services as set of consultancy, reengineering and educational services) - as an education system and developments of intellectual potential of the nation and as one of the main spheres of production of innovations - creates the main conditions for the progressive growth of the markets on the basis of continuous improvement of technologies and products. The field of intellectual services is provided to one of the first links of the innovation cycle "education-researches-mass development of innovations" (Russian education - 2020: education model for the economy based on knowledge, 2008). Thus the sphere of intellectual services is provided, not only as a necessary link of reproduction of an intellectual capital, but also as a fundamental element of the economic growth defining stability of external and internal competitive advantages of virtual and information economy of modern Russia.

From capability of national economy to reproduce the individual and public intellectual capital implementing the level of economic thinking of the nation, substantially, the economic force, welfare, a choice of its strategy and a trajectory of the subsequent development of virtual and information economy, globalization in the long term is defined.

In this regard before the sphere of intellectual services there are priorities demanding the immediate decision, caused by need of compliance to transformational changes of educational sector:

1. To the innovation system of development of the economy of Russia.

2. To social requests of suppliers and consumers of the sphere of intellectual services.

To requirements of globalization, the universal competition of producers in the markets of innovations, work, and 
educational services.

\section{Methods and Materials}

Determination of global world space on the basis of virtual and information economy regulates communication of the last with social design of the sphere of intellectual services and predetermines a choice of the general vector of transformation of social and economic systems, historical logic of structurally functional modernization of the sphere of intellectual services, and also sector of institutional mechanisms of implementation of transformational dynamics of the field of intellectual services.

In other words transformation of the area of intellectual services is not only transformation of the contents and functions of the specific sphere of society, this actual condition of optimization of changes of national economy (it is unambiguous also national innovation system). As significant changes of an implementable measure within which there is a choice of the most essential and perspective direction, there is a flexible adaptation national (regional, local) the market for intellectual services to changes in global external environment through forming and development of new target programs, innovation projects and technologies.

For theoretical judgment of the happening global changes of cognitive features (i.e. determined by the contents, character and the mechanism of creation, distribution and use) modern economy on macro - and microlevel terms, "information economies" (Uebster, 2004) "new economy" are used (Deming, 2006 \& Karepova, et al. 2015), "economy of knowledge" (Makarov and Kleyner, 2007 \& Magsumov, 2013) and "the economy based on knowledge" (Spepanova and Manokhin, 2008 \& Magsumov, 2014) within which different effects of an exponential increment of volume of the knowledge and the increasing rates of aging of information connected with that are investigated that $70-85 \%$ per annum of gains of GDP in the conditions of post-industrial development are provided with use of system knowledge in different areas of human activity.

Within the second direction to the research of lifecycle of knowledge the specific stages capable to consider the non-material nature of knowledge, features of their transfer and methods of use are allocated. So, in the researches devoted to knowledge management the following stages of lifecycle of knowledge "allocations - acquisitions developments - uses - distribution - preserving" as the key moments of knowledge management are allocated (Probst, Raub and Romhardt, 2000). Let's note that in the researches devoted to knowledge management stages of lifecycle of knowledge on the basis of project management in the form of the logical model of knowledge (logical knowledge model) including the following stages of lifecycle of knowledge "acquisition - abstraction - increase - storage - utilization" are considered (Sugumaran and Tanniru, 2002).

Research of lifecycle of knowledge on the basis of the dynamic development of the last is described in Helfat and Peteraf's work who suggested considering "lifecycle of capability/competence" Helfat and Peteraf (2003). Some stages enter this cycle: creations, developments and a maturity, and on reaching the last (or even before it) can influence the further evolution of different capability events. The lifecycle of capability/competence is reflected in Figure-1.

Apparently from Figure-1 eventually the resultant stage of further development can be provided, for example, to one of six additional kinds of stages of the considered cycle: retreat (death) (retirement (death)), restriction of expenses on maintenance of competence (retrenchment), updating (renewal), replication (replication), redistribution (redeployment) and recombination (recombination) Helfat and Peteraf (2003).

They can follow one after another in different possible sequences during the long temporary period. Some of these transitional stages can also take place at the same time. It is important that in each transition from one stage of the lifecycle to another evolutionary dependence on the previous direction of development of lifecycle of capability remains that in turn has an impact on perspective dynamics of its development.

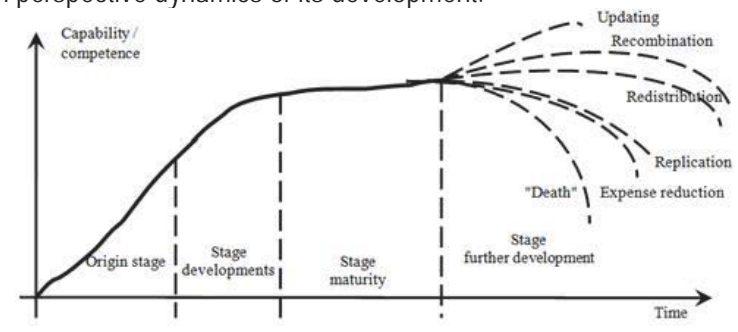

Figure 1 - Lifecycle of capability/competence (Helfat and Peteraf, 2003) 
From the point of view of dynamic aspect of lifecycle of intellectual services it is important to understand that exact replication of intellectual services from the "strong" supplier of intellectual services to "weak" promotes adaptation of weaker to external conditions of the market environment as weaker suppliers of intellectual services, than stronger receive from benefit integration (Maritan and Brush, 2003) more. Besides, many authors consider that in the field of intellectual services adaptation follows the correct replication of competences to local market conditions of work that leads to optimum work of the educational organization, than adaptation without the undertaken replication (Szulanski, Winter, Cappetta and Van den, 2002).

For higher education institutions in the conditions of globalization and an exit to international markets, the stage of redistribution and replication of competencies within intellectual services can actively be used. The stage of redistribution differs from a replication phase, that replication is used as expansion of an exit to new geographical markets of intellectual services when opening new branches, and redistribution is applied as an exit to new segments of the market of intellectual services.

Specifics of a transfer of knowledge and its lifecycle are expressed that even if the supplier of intellectual services will disappear as legal entity from the market of intellectual services, however, the approaches to implementation provided to them of intellectual services can exist in the market and change. Especially it is actual at the merge of different suppliers of intellectual services (Winter, 2000 \& Magsumov, 2015).

Competitiveness of the sphere of intellectual services by us is understood as significant superiority, competitive advantage in strategy and tactics of providing service for the purpose of more efficient satisfaction of requests of the population and to increase in profit.

From the point of view of system approach, the greatest attention should be paid classifications of competitive advantages of intellectual services in some signs. It is possible to distinguish the following from these signs: an origin source (as factors of external environment reflect synthesis of conditions for which the enterprises of the sphere of intellectual services adapt, and internal - cause both the potential, and productivity of process of adaptation), stability degree, activity profiling, functional accessory, the action period, possibility of reproduction, extent of protection, level of innovation (tab. 1).

Table 1 - Classification of Competitive Advantages of Intellectual Services

\begin{tabular}{|c|l|l|}
\hline № & The classification sign & Groups \\
1 & Service origin source & competitive advantages \\
2 & Degree of stability of service & Steady, partially steady, not steady \\
3 & Service activity profile & The innovation, marketing, information, economic, technology and, etc. \\
4 & Service action period & Short-term, medium-term, long-term \\
5 & Possibility of reproduction of service & Hard to reproduce, easily reproduced \\
6 & Extent of protection of service & Availability corresponding to the license, patent, certificate \\
7 & Level of innovation of service & Radical, modernized, modified, complex \\
8 & Functional accessory of service & Location, partnership (business connections), goodwill (positive reputation), etc. \\
\hline
\end{tabular}

Let's note that along with the offered classification of competitive advantages of intellectual services, the interrelation of conditions of competitiveness and criteria of their assessment is of particular importance. The state has to create life activity conditions for the enterprises of the studied sphere. Potential opportunities for the organizations depend on a skill level, professional readiness, competencies, experience, innovative qualities and responsibility of the management, which has to perform efficient management, increasing competitive advantages of the offered intellectual services.

The express research in history gives us an idea of the permanence of its development and stable aspiration to perfection; we will note that at achievement of level of knowledge, people become more active to new and new knowledge, directing the efforts to quantitative and high-quality measurement and transformation of the appearing material and spiritual, environmental feature. It should be noted that the specified feature extends in all areas of life activity: social, technical, ethical, cultural and scientific, of course, the economic. Having analyzed the development of the history of the economic relations, it is possible to allocate three global periods. For convincing visualization, it is comparable these stages to the development of the person.

The first period belongs to an era of agrarian society. It is the period it is possible to provide a certain childhood of humankind, the period is characteristic domination of a collective focus of interest (non-material or material), private interests stood aside.

The second period belongs to industrial age - the humankind "stepped" in development as a result of the industrial 
revolution. The specified period is called humankind youth, more and more new and perfect ideas captured people on improvement of the life activity.

Third stage. The industrial relations change in post-industrial, thus, there is a modern period of formation of societies all life activity of the person. Society, in general, life activity of mankind, is mature and wise, with a set of intellectual potential, permanent at an initial stage. Production and cars as an analog of force, pass into the background. To the forefront, there is intelligence and knowledge as an analog of suspension and wisdom of the mature person and society in general. This period of economic development scientists-economists call "post-industrial", "virtual economy", "information economy", "network economy". There is a considerable number of opinions and points of view on "new" or "post-industrial" economy and the mass of its determinations and treatments.

Once with Inozemtsevy V. L. agrees (Inozemtsev, 2000) that in the post-industrial society considered above the wealth and a solvency more is associated with ownership of knowledge and information. These features become an entry condition of an increase in production efficiency and, thereby, create that wealth, "which assignment by these owners provides the increasing irregularity in the distribution of national property". Doing an intermediate result, we will note that as the main dynamic tendencies of post-industrial economy consider the following:

- First, the growth of intellectual capacity and fullness, both services (goods), and processes of their promotion and sale;

- Secondly, "customization" of present commodity space, a tendency to the maximum and exhaustive embodiment in a product of requirements final (or it is more correct to tell, specific) the consumer;

- Thirdly, intellectualization of the distributed / complex decisions. According to a tendency of "customization" "the intellectual knowledge" is guided not by the price, namely by total ownership cost, by the amount of positive effects and benefits, received by the consumer who will look for the most complex decision and advantage for himself;

- Fourthly, "virtualization" of economic communications. Service (service industry), goods as a physical item of the economic relations gains the increasing strength of "virtualization", losing the material basis / cover, the maintenance of goods in physical expression recedes into the background more and more. Service (goods) turns into intellectual and information maintenance, and then is implemented in the general complex of the accompanying services;

- Fifthly, intellectual "brightness" of the economy becomes so significant that the cost of separate companies and firms already in many respects forms from knowledge assets, non-material (Zabrodin, 2008, p. 16-25);

- Sixthly, to the present period of forming and development of a society of the XXI century such distinctive property as informatization - "... The difficult social process connected with considerable changes in a way of life of the population is characteristic. He demands serious efforts in many directions, including liquidation of computer illiteracy, forming of the culture of use of new information technologies, knowledge, etc." (Intellectual services in an informational society: the scientific monograph, 2009, p. 79).

Distribution of information in the field of intellectual services is equivalent to its self-increase that excludes application to this phenomenon of the concept of a rarity. Consumption of information does not cause its expenditure as productive resource, thus, supporters of the theory of an informational society came to the logical in general thesis that "in modern economy the rarity of resources is replaced with their prevalence" Crawford, R. (1991).

\section{Results}

In the works devoted to information technologies, the tendencies of an intensification and informatization of work of workers in modern economy, which are shown directly that, are noted:

1. In recent years in the modern economy, the steady tendency of growth of representatives of society with $\mathrm{HPE}$ (higher professional education) in economically active part of the population is noted.

2. Now at production and sales activity there is (with dynamics of growth) a large number of the workers occupied "with manipulations with symbols", "workers of knowledge" to which job responsibilities belong collecting, processing and information analysis (more than $60 \%$ of newly created workplaces are connected with information processing).

3. Today, the number of the professional features and workplaces connected with the use of the computer and electronic technologies increases.

4. Growth of investments into the intellectual potential leading to rising the educational level of the population makes a positive impact on long-term economic growth and development. 
The connection of processing of information and processes of its delivery led to the development of communicative information technologies that significantly accelerated processes of informatization and intellectualization of work. From the point of view of this approach - knowledge is based on development and change of information and communication technologies.

We can tell that the modern sphere of intellectual services is at that stage of the forming and development when to the main plan there is intelligence and knowledge. In turn, intellectual service and intellectual capital become a fundamental factor, and ownership of intellectual property - the priority direction of the business. High-speed of decisionmaking, change (fast, continuous and challenging); create uncertainty and reduce predictability. Time and information act as driving forces, as well as such significantly significant aspect of the development of the modern world as globalization.

It is possible to notice that the globalization of the economy (its virtualization and informatization) promotes the development of the sphere (intellectual and virtual) services. It is worth noticing that initially the market of services arose as an appendage to the available goods market. However, demand for all types of service, in process of saturation of a market niche goods and complications technology and production process, intellectualization, customization and need of forming and development of complex offers and other accents of present "knowledge society" ("society of knowledge") Inozemtsev (2000), tends the strong growth and development. In the prevailing majority of developed countries, the service industry exceeds the production sphere not only on growth rates and on emergence of new types of service, but also and on its adaptation to requirements of the market.

It is worth agreeing with Tultayev T.A. (Tultayev, 2005, p. 97) that the principal reasons for a bigger role in the service industry in modern economy are represented, first of all, in emergence of new types of activity, with increase of potential of scientific and technical progress, in complication of innovations and production processes and overflow of the market subjects of daily demand. Growth of the importance of the service industry in the XXI century is obliged to increase in influence of services at trade in the innovation types of goods and conditions of their use in everyday life of the person, in particular technically difficult; need and need for a complex of additional services at sale of goods; increase of transport, financial, information and other services in connection with development of production and its technical features.

The increase in value of a role of the service industry did not pass in structure of national economy of the countries of the world completely: over $40 \%$ of the foreign direct investments placed in a global economic system are implemented in the field of services (including: in trade, banking services, and insurance); growth of a share of services in GDP of developed countries of the world over $70 \%$ of synchronous increase in a percentage occupied in the field of services; 80 $-90 \%$ of a gain of new workplaces happen in the service industry (Tultayev, 2005, p. 8).

Distinctive feature of import and export of the service industry is that results of their providing, for example material, will not cross a customs border of the country therefore at world trade by services there are no customs duties that are important feature from the point of view of economy on production. Import and export of services will be performed by opening of representations and branches of the organizations - contractors of services in other countries, and in the conditions of globalization it became one more motive to forming and development of the service industry.

The analysis of economic literature allows noting that the global transformation of the economy and the economic relations in the course of transition from the industrial period of development of society by the post-industrial period accompanies the expansion of services. The service industry acts as one of significant and essential sources of GDP growth and a central subject of reduction of the number of unemployment using providing new workplaces. It is noted that the transition of labor power from all industries of production of goods in the service industry and the valid increase of equity in an gross internal product it was designated by a universal tendency. Let us compare two moments:

1) Fruitfulness of intellectual production now is basic accent in global competitive struggle whereas the knowledge acts as the main resource;

2) Services make an essential share of GDP of the majority of developed countries.

It should be noted that today the sphere of intellectual services is actual, more competitive and demanded in the system of the world economic relations. Here it is lawful to speak about such new economic concept as "world economy of intellectual services". 


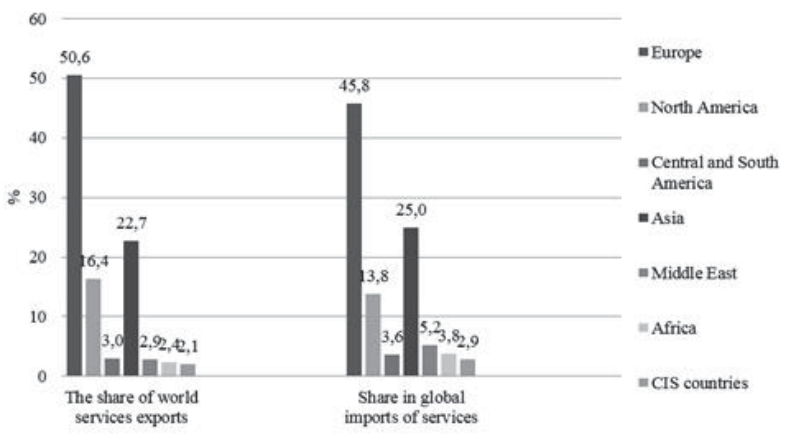

Figure 2 - World trade in services in developed and developing countries in 2014; (in \%) (World Trade Report, 2010)

It is necessary to agree with Agababyan E. (2003) that before economically active population of all countries of the world the problem opened - to find acceptable and efficient forms of control and planning, regulation and management of the sphere of all production of intellectual services on the scale of the world economy. At the present stage of development of the economic relations, in trade in services around the world including intellectual, dominant position is taken technology and industrialized countries of Europe, North America, and also South Korea and Japan specializing mainly in financial, telecommunication, information, educational and medical services. The share of the listed countries makes more than $50 \%$ of world trade of the service industry. In developing countries, specific weight in trade in services in the global marketplace occupies considerably a smaller share; they provide tourist, transport and financial and offshore services. Services in developed and developing countries for 2009 we will display a share of world trade in Figure-2.

The Russian Federation is also the exporter and the importer of services. During 2000-2012 value of foreign economic relations of the Russian Federation significantly increased. Let's note that the foreign trade turnover of services (and goods) made by 2012 up to $60 \%$ of volume of GDP, and financial resources from external trade activities create the most significant share of financial receipts of the enterprises and higher than $40 \%$ of receipts in the federal budget of the Russian Federation (Intellectual services in an informational society: the scientific monograph, 2009). The structure of export and import of services of Russia in world trade and economic system it is provided in Figure-3.

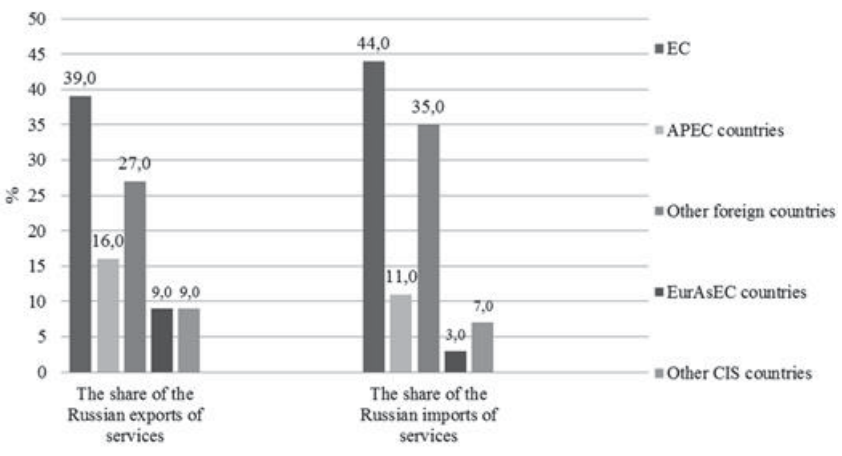

Figure 3 - Structure of the Russian export and import of the services in groups developed and developing countries in 2014; (in \%) (Official data of Bank of Russia: Foreign trade of the Russian Federation in services, 2009)

If to concentrate on site Russia in the world, the share of raw materials and materials in the total amount of export reaches $80 \%$, whereas cars and equipment, including military equipment - only $5-7 \%$. The Russian share in world turnover of goods and services decreased, in comparison with the pre-reform period, from 2,5\% approximately to 1,7\%. The perspective horizons are opening because of the development of new territories, new types of minerals and scientific and technology transformations in the world apply in Russia obviously insufficiently, despite quite an essential potential. With respect thereto, research and the analysis of the real sphere of intellectual services actually for Russia, is present 
the main resource of an intensification of modern development of society because of knowledge in this direction, the human capital that is much more expensive than any other resource presently is criticized.

Let's allocate that insufficient sale of intellectual potential of the country and reserved modernization plunges low competitiveness of the Russian sphere of intellectual services on a global scale that in turn slows down transition of the industrial period of development of all society to the post-industrial period.

Thus, development of virtual and information economy led to radical modifying's of conditions of maintaining entrepreneurship, expansion of the sphere of rendering intellectual services (Szulanski, Winter, Cappetta and Van den, 2002 \& Novikov, et al., 2015).

Influence of Internet of technologies, online-of operating modes on the idea of methods and forms of implementation of economic activity does not limit the use of the developed technologies information (and virtual) economies. On the contrary, the found instruments of information and communication ensuring financial and economic activity make a radical impact on methods of implementation of the business activity. Business processes are transformed, business models are reviewed, and the new corporate (organizational) culture forms and develops. Customer relations and business partners switch to the new high level of development.

Virtual and information economy managed to offer new ways of growth and improvement of the companies (Novikov and Novikova, 2012). Social and economic progress is made due to change of the concept of operating activities, the establishment of closer partner relations and clients. The new economic basis of electronic entrepreneurship consists inefficient audience accumulation, an increase of productivity of marketing activity, forcing of sales processes and purchases of all types of goods (services).

\section{Conclusion}

Virtual and information economy shows considerable influence on results of activity of the enterprise thanks to reduction of duration of business cycles, improvement of quality of the services provided to clients, cost decrease in the course of the main economic activity, and, therefore, and increases in a market share. Virtual and information economy is not limited only to technology elements; actually, it has a considerable impact on fundamental parts of strategic management and economic activity of any enterprise and organization.

Is usual for Internet of technologies and online of operating modes the decisions, which are based on open standards of architecture of system of virtual, and information economy, which provide high adaptation and potential of improvement of system that allows it to function with the minimum costs. It is necessary to emphasize that application of open standards, public information resources, and infrastructure provides to system more availability to destructive influences from criminal structures, competitors and private person's hackers.

\section{References}

Agababyan, E. (2003) World economy of intellectual services: state, tendencies and regulation.//Problems of the theory and management practice. № 6. URL: http://vasilievaa.narod.ru/ptpu/4_6_03.htm.

Deming, E. (2006) New economy. M.:eksmo. pp. 208.

Zabrodin, A.Yu. (2008) Intellectual services in business: a handbook. M.: ZAO "Publishing House "Ekonomika". pp. 635.

Inozemtsev, V.L. (2000) Modern post-industrial society: nature, contradictions, perspectives. M.: Logos. pp. 304.

Intellectual services in an informational society: the scientific monograph (2009) / G.V. Astratova and A.A. Kopchenov. General and scientific edition. - Chelyabinsk: ChGAA. pp. 212.

Makarov, V.L. and Kleyner G. (2007) Microeconomics of knowledge. M.: Economy. pp. 204.

Novikov, V.S. and Novikova Yu.I. (2012) Research in operation integrated marketing communications as elements of informatization and virtualization of economy//Economy and entrepreneurship. No. 3. pp. 207-212.

Novikov, V.S. (2009) Public-private partnership as the mechanism of transformation of the sphere of educational services in the Russian Federation: the thesis of Candidate of Economic Sciences. Rostov N / D. pp. 209.

The main methods of forming of chains of the addition of consumer cost in a cyberspace. URL: http://k-lan.narod.ru/Crypto/oeb_p2.htm

Official data of Bank of Russia: Foreign trade of the Russian Federation in services (2009)//Rossii.s.2 Bank.URL: www.cbr.ru/statistics/ credit_statistics/trade.pdf.

Russian education - 2020: education model for the economy based on knowledge (2008)//The IX International Science conference. "Modernization of economy and globalization," Moscow / under the editorship of Ya. Kuzminov and I. Frumin; State University. Higher School of Economics. M.: Prod. House of GU HSE. pp. 39.

Spepanova, T.E. and Manokhin N.V. (2008) Ekonomika based on knowledge (the theory and practice). M.: Gardarika. pp. 238.

Magsumov, T. A. (2015). The additional professional training in the late Russian empire. Bylye Gody, 36(2), 327-337.

Magsumov, T. A. (2013). Educational excursions in technical schools of pre-revolutionary Russia. Bylye Gody, 27(1), 52-60. 
Tultayev, T.A. (2005) Service marketing. M.: MFPA. pp. 97.

Uebster, T. (2004) Theories information" societies. / F. Uebster. M.: Aspect Press. pp. 400.

Crawford, R. (1991) In the Era of Human Capital. L.-N.Y. pp. 11.

Helfat, C.E. and Peteraf M.A. (2003) The Dynamic Resource-Based View: Capability Lifecycles // Strategic Management Journal. Vol. 24. N 10. pp. 997-1010.

Maritan, C.A. and Brush T.H. (2003) Heterogeneity and Transferring Practices: Implementing Flow Manufacturing in Multiple Plants /I Strategic Management Journal. Vol. 24. Special Issue. N 10. pp. 945-959.

Probst, G., Raub S. and Romhardt K. (2000) Managing Knowledge: Building Blocks for Success. Chichester: John Wiley \& Sons.

Sugumaran, V. and Tanniru M. (2002) Life Cycle Based Approach for Knowledge Management: A Knowledge Organization Case Study // Conference of Advanced Information Systems Engineering / Eds. A. Banks Pidduck et al. Berlin, Heidelberg: Springer-Verlag. pp. 766-769.

Szulanski, G., Winter S. G., Cappetta R. and Van den Bulte C. (2002) Opening the Black Box of Knowledge Transfer: The Role of Replication Accuracy // Working Paper Series. The Warton School, University of Pennsylvania.

Winter, S.G. (2000) The Satisficing Principle in Capability Learning // Strategic Management Journal. Vol. 21. N 10-11. pp. 981-996.

Magsumov, T. A. (2014). Main approaches to the study of historical and educational process. Bylye Gody, 34(4), 720-726.

World Trade Report (2010) // World Trade Organization. pp. 29. URL: http://www.wto.org/english/res_e/booksp_e/world_trade_ report10_e.pdf.

Novikov, V.S., Klochko E.N., Yarushkina E.A., Zhukov B.M. and Dianova V.A. (2015) On peculiarities of the virtual economy of modern Russia: categories, virtual relationships, educational constructs. Mediterranean Journal of Social Sciences, 363 (247-257).

Karepova, S.G., Karabulatova I.S., Klemovitsky S.V., Novikov V.S., Stratan D.I. and Perova, A.E. (2015) New approaches to the development of the methodology for strategic community planning. Mediterranean Journal of Social Sciences, 363 (357-363).

Novikov, V.S., Klochko, E.N., Yarushkina, E.A., Zhukov, B.M. \& Dianova, V.A. (2015) On peculiarities of the virtual economy of modern Russia: categories, virtual relationships, educational constructs. Mediterranean Journal of Social Sciences, 363 (247-257).

Karepova, S.G., Karabulatova, I.S., Klemovitsky, S.V., Novikov, V.S., Stratan, D.I. \& Perova, A.E. (2015) New approaches to the development of methodology of strategic community planning. Mediterranean Journal of Social Sciences, 363 (357-363). 